Current Research Journal of Biological Sciences 12(1): 1-5, 2020

DOI: $10.19026 /$ crjbs. 12.6036

ISSN: 2041-076X, e-ISSN: 2041-0778

(C) 2020 Maxwell Scientific Publication Corp.

Submitted: September 13, $2019 \quad$ Accepted: January 16, 2020

Published: April 20, 2020

\title{
Research Article \\ Detection of Unexpected Fungi and Bacteria on Daily Most used Iraqi Notes in Sulaimani City
}

\author{
Sabiha Sharif Salih and Mariwan Abdullah Hama Salih \\ Medical Laboratory Department, Technical College of Health, Sulaimani Polytechnic University, \\ Sulaimani, Iraq
}

\begin{abstract}
The aim of this study is to evaluate the level of contamination of Iraqi bank notes with pathogenic bacteria and other microorganisms. Paper currency and coins can be considered as active sources of some human pathogens were possibility combined with the contaminated food and could lead to spread of microbial infection. In this study some pathogenic bacteria and fungi were isolated from the sample of currencies $(250,1000$ IQD and Coins). Over all (40) samples were collected randomly. All samples were tested for bacteria and fungi detections, the percentage of isolated bacteria and fungi depended on the percentage of growth in 1000 IQD. The percent of isolated bacteria E.coli, Staphylococcus aureus, fungi Staphylococcus. epidermidis, Klebsiella. oxytoca and Pseudomonas. spp were found $(33.30 \%, 26.60,26.60,13.30,13.30,13,30)$ respectively. The percent of fungi and bacteria isolated from 250 IQD for Staphylococcus. aureus Pseudomonas. spp, E. coli, Staphylococcus. Epidermidis and fungi were found $(33.30,33.30,26.40,26.40,13.30 \%)$ respectively. The percent of isolated bacteria and fungi that were growth on coins were different from the paper notes (1000 and 250 IQD). Ten percent of these samples were no bacteria or fungi growth isolated, while growth for E. coli isolated were (20\%), for Proteus spp (20\%), Klebsiella. Oxytoca (20\%), no growth $(10 \%)$, Pseudomonas. spp, $(10 \%)$ and fungi $(5 \%)$. For all isolated bacteria ten antibiotic sensitivity tests were performed including (Amikacin AK Ampicillin Amp, Amoxicillin Amx Cephalosporin Cef, Ciprofloxacin Cip, Gentamycin Gm., Rifampicin Rif, Nalidixic Acid (NA), Tetracycline Tet and Trimethoprim Tri), In this study multiple antibiotic resistance were seen.
\end{abstract}

Keywords: Antibiotic resistance, bank notes, contaminated currency, Iraqi currency, isolated bacteria

\section{INTRODUCTION}

In ancient times, people didn't need money, they got everything they needed through bartering. In bartering, you trade something you don't need for something you do need. Thousands of years ago, the first money was commodity money. Commodities are things that everyone values enough to trade for and accept as payment. Commodity money varied from place to place, depending on what the local people valued. E.g., Shells, salt and iron nail. But many forms of commodity money were difficult to carry and could lose their value. In due course, these were replaced by coins (pieces of metal) made of gold, silver, bronze and copper and much later paper money was developed the first time in China (Investopedia 2010) and (National Banking Eras Philadelphia fed. org).

Money is the most widely used and sought-after service on the planet. The transfer of paper currency has been the miniature of commercial exchange since its introduction in China circa 1000 AD In Bernholtz (2003) 1800 s and early 1900 s, analyst began to project that the transmission of money was associated with the conveyance of disease (Schaarschmidt, 1884) Modern scientific techniques have accepted these theories and have shown that viable pathogenic organisms (viruses, bacteria and fungi) can be isolated on the surfaces of both paper and coin currency (Kuria et al., 2009; Lamichhane et al., 2009). Modern banknotes are made from a special blend of cotton, linen, other textile fiber and animal gelatin for the surface coating of banknotes with slice of fiber. The cotton/ linen/fiber combination of banknotes make of a strong bond and do not pull apart, unlike the fibers of ordinary paper. Recently many countries have been recovered banknotes from paper to plastic polymers substrate (Ahlers et al., 2010). Although the primary purpose for the increase of this plastic polymer's substrate was to enhance security, it has been explained that this material provides other advantages i.e., it has a higher tear support paper, more resistant to folding and soiling, it is nonporous and it does not swallow water or sweat. Given these characteristics, polymer banknotes may be cleaner than paper currency (Vriesekoop et al., 2010; Ahlers et

\section{Corresponding Author: Sabiha Sharif Salih, Medical Laboratory Department, Technical College of Health, Sulaimani} Polytechnic University, Sulaimani, Iraq

This work is licensed under a Creative Commons Attribution 4.0 International License (URL: http://creativecommons.org/licenses/by/4.0/). 
al., 2010). Studies have shown that polymer-based banknotes often have a relatively low bacterial count compared with the cotton-based 'paper' banknotes. This may be due to various physicochemical parameters of polymers (Vriesekoop et al., 2010; Prasai et al., 2008).

The most common nosocomial pathogens remain on the surfaces of bank notes for months and can be the source of transmission (Kramer et al., 2006). The possibility that currency notes might act as environmental vehicles for the transmission diseasecarrying microorganisms was suggested in the 1970 (Abrams and Waterman, 1972). Paper notes of currency which is handled by a large number of people increase the possibility of acting as environmental vehicle for the transmission of potential pathogenic microorganisms (Feglo and Nkansah, 2010; Oyero and Emikpe, 2007; Nasser and Alwakeel, 2012).

Herein this study was performed in order to show new generation and publics that bank notes could be one of the main reasons for illness.

\section{MATERIALS AND METHODS}

Local bacterial isolates: Forty (40) samples from currency Iraqi (1000, 250 and coins) were taken randomly in Sulaimani city Iraq during April to May (2018-2019) all samples were tested for microbial (bacteria and fungi) the sample was add to $10 \mathrm{~mL}$ sterilized distil water after shaking the samples added to $50 \mathrm{~mL}$ of broth agar medium and incubated at $37^{\circ} \mathrm{C}$ for 24-h after incubating period.

All samples were inoculated on selective medium such as (Eosin Methylene Blue Agar). MacConkey agar, blood agar, Sabouraud Dextrose Agar (SDA) and Mannitol Salt Agar (MSA) although all isolated were diagnosis depending Culture, Morphological and biochemical analysis according to Andrews and Hammack (2000) moreover API20E system was performed for analytic bacteria. The Isolates obtained from culture samples were identified as Described by Alton et al. (1988).

Antibiotics used: The susceptibility of the all isolated bacteria from currency Iraqi (1000, 250 and coins) were tested for antibiotic sensitivity against (Amikacin AK Ampicillin Amp, Amoxicillin Amx Cephalosporin Cef, Ciprofloxacin Cip, Gentamycin Gm., Rifampicin Rif, nalidixic acid (NA), Tetracycline Tet and Trimethoprim Tri) was using Disk diffusion method (Atlas et al., 1995).

\section{RESULTS}

Total (40) samples were collect from different part which transported money and some of the samples from the present money all samples were tested for isolating microbial (bacteria and fungi) according to
Table 1: Percentage of bacterial growth collected on 1000 IQD paper

\begin{tabular}{lll}
\multicolumn{2}{c}{ money } & \\
\hline Positive samples & Bacteria and Fungi & Growth \\
\hline $1,2,4,6,14$ & E. coli & Percentage (\%) \\
$6.8 .9,11$ & Staphylococcus aureus, Fungi & 26.30 \\
3,12 & Klebsiella oxytoca & 13.30 \\
5,7 & Pseudomonas & 13.30 \\
10,15 & Staphylococcus epidermidis & 13.30 \\
\hline
\end{tabular}

Table 2: Samples are collected from IQD coins

\begin{tabular}{lll}
\hline Positive samples & Bacteria and Fungi & Growth \\
\hline 31,34 & Proteus & 20 \\
32,40 & E.coli & 20 \\
38,40 & Klebsiella oxytoca & 20 \\
35 & No growth & 10 \\
33 & Pseudomonas. spp & 10 \\
$36,37,40$ & Fungi & 5 \\
\hline
\end{tabular}

Table 3: Samples are collected from 250 IQD paper money

\begin{tabular}{lll}
\hline Positive samples & Bacteria and Fungi & $\begin{array}{l}\text { Growth } \\
\text { Percentage (\%) }\end{array}$ \\
\hline $16,20,21,23,28$ & Staph. aureus & 33.30 \\
$17,18,20,22,24$ & Pseudomonas spp. & 33.30 \\
$19,27.28,29$ & E. coli & 26.40 \\
$21,25,29,30$ & Staph epidermidis & 26.40 \\
23,26 & Fungi & 13.30 \\
\hline
\end{tabular}

microbiological lab depending on biochemical analysis and API20E used for diagnosis gram negative bacteria. From the (40) samples of Iraqi currencies (1000, 250 and coins) were taken randomly, in some place were exchanging money in Sulaimani city. This research showed that six types of bacteria were isolated from Iraqi currencies (1000, 250 and coins) which is shown in Table 1 to 3 while the percentage of fungi isolated $(26.60 \%, 5 \%, 13,30 \%)$ Table 1 to 3 .

While the most micro-organism isolated from Iraqi dinar and coins were E. coli, Pseudomonas. spp, Staphylococcus. aureus, fungi, Staphylococcus. epidermidis, Klebsiella. soxytoca. and Proteus spp although the least percentage bacteria were Proteus. spp which was shown in Table 1 to 3. The Storage of money on dirty surfaces leads to contamination while these reasons will be act on microbial growth and contaminate the hands of the next user. The money makes for easy transfer microbial although it was clear in this research and antibiotic resistance were tested for bacteria isolated which shown in bio gram antibiotic sensitivity test Table 4 to 9 while the (10) commonly antibiotic were used which was (Amikacin AK, Ampicillin Amp, Amoxicillin, Amx Cephalosporin, Cef, Ciprofloxacin, Cip, Gentamycin, Gm, Rifampicin, Rif, Nalidixic acid (NA), Tetracycline, Te and Trimethoprim, Tri).

Although some of these samples which were $E$. coli (samples 40, 28) Pseudomonas. Spp (samples 5, 7) Klebsiella oxytoca (samples 13, 38) and (Proteus. spp samples $(31,34), 100 \%$ resistance for all antibiotic which was shown in Table 4 to 9. Although Multi drug resistance were found in all isolates for many types of 
Curr. Res. J. Biol. Sci., 12(1): 1-5, 2020

Table 4: E. coli

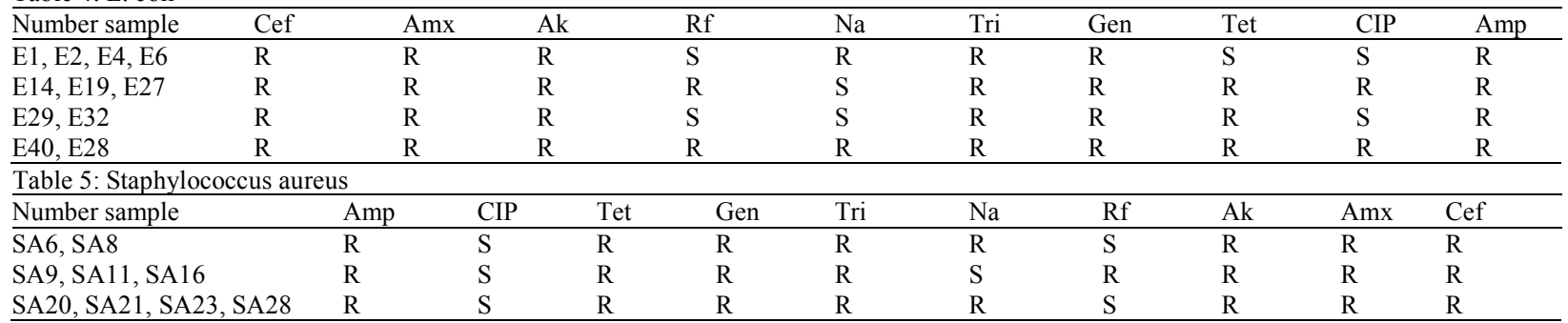

Table 6: Pseudomonas. Spp

\begin{tabular}{lllllllllll}
\hline Number sample & Amp & CIP & Tet & Gen & Tri & Na & Rf & Ak & Amx & Cef \\
\hline P17, P18, P20 & R & S & S & R & R & R & S & R & R & R \\
P22, 24 & R & R & R & R & R & R & R & S & R & R \\
P5,7 & R & R & R & R & R & R & R & R & R & R \\
\hline
\end{tabular}

Table 7: Klebsiella oxytoca

\begin{tabular}{lllllllllll}
\hline Number sample & CIP & Amp & Tet & Gen & Tri & Na & Rf & Ak & Amx & Cef \\
\hline K3, K12 & S & R & S & S & R & R & S & S & R & R \\
K13, K38 & R & R & R & R & R & R & R & R & R & R \\
\hline
\end{tabular}

Table 8: Staphylococcus epidermidis

\begin{tabular}{lllllllllll}
\hline Number sample & CIP & Amp & Tet & Gen & Tri & Na & Rf & Ak & Amx & Cef \\
\hline SE10, SE15 & S & R & S & S & R & R & S & S & R & R \\
SE21, SE25 & S & R & R & R & R & R & R & S & R & R \\
SE29, SE30 & S & R & R & S & R & S & S & S & R & R \\
\hline
\end{tabular}

Table 9: Proteus spp

Number sample

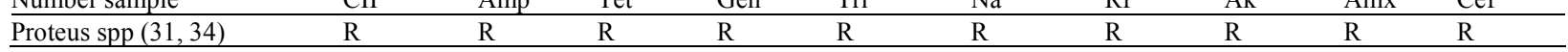

antimicrobial, while some isolated were resistance for (Amp, Gen, Tri, Ak, Amx, Cef) $100 \%$ and the percentage growth of other isolated (E. coli) from (1000, 250, coin), $(33.3 \%, 26.40 \%$., 20\%) Fig. 1 to 3 and Table 1 to 3 while for the other isolated the percentage was shown in (T1, T2, T3) .Although the lower percentage for fungi , and some bacteria growth determined in coins which was shown in (T1, T2, T3)and Fig. 1 to 3 while the percentage growth of Pseudomonas. spp, Staphylococcus. aureus, fungi, Staphylococcus. epidermidis in (250 IQD) more than 1000 IQD and coin While the rate growth of Klebsiella oxytoca in coin higher than (1000 IQD) and the ratio for fungi in 1000 IQD more than 250 IQD and coins.

\section{DISCUSSION}

This Research was shown that currency paper and coins serve as an ideal breeding ground for microorganisms for several reasons. The material compound of paper and surface area help for microorganisms to collect and contamination (Ayandele and Adeniyi, 2011).

Studies indicate that the age and denomination of a bill have a direct correlation with the contamination observed (Pradeep et al., 2012). Improper hand washing after using the toilet, counting paper notes using saliva, coughing and sneezing on hands especially for paper notes then exchanging money and storage of paper notes on dirty surfaces leads to the contamination and these notes will act as a vehicle delivering bacteria to contaminate the hands of the next user. The money makes for easy transfer of bacterial and thus cross contamination (Ayandele and Adeniyi, 2011).

Pradeep et al. (2012) and Lamichhane et al. (2009) Physical transfer of material from hands, surfaces and the environment can contaminate currency (Tagoe et al., 2009) Individuals from almost every socioeconomic background routinely hold and transfer paper currency.

Contamination currency in this study by different pathogenic bacteria and fungi were importance on health as contaminated materials can be possible sources of transmission of such pathogens. Bacteria have been shown to be spread from person to person via contact with. Currency is routinely passed among individuals. Thus, bacteria could be spread on the surface of paper currency (Barolia et al., 2011) Investigator suggest that dirty currency could host harmful micro-organisms which are also deposited on currency counting machines and the counting rooms' environment thereby posing risk to customers and bankers alike Ahmed et al. (2010). Money, therefore presents a particular risk to public health, since communicable diseases can spread through contact with fomites (Awe et al., 2010; Shekarforoush et al., 2009; Elumalai et al., 2012). 
Several researches reported that increased Contamination currency and coins could (Enemuor et al., 2012) serve as vectors for the transmission of several diseases (Bhat et al., 2010).

Microbial may be transmitted directly, through person to person or indirectly food or drink or other objects. Although some study object there were different bacteria found and isolated from notes in Indian while the notes contamination by some bacteria Pseudomonas. spp, E. coli, Staphylococcus. aureus, Vibrio cholerae (Umeh et al., 2007; Ahmed et al., 2010) these research like your research and in this study determined some bacteria contamination currency IQD and coin some of these bacteria pathogenic for human and some of them nosocomial and other opportunistic bacteria. Some bacteria normal flora presents in environmental although the reason of contamination currency and coin the paper and material which made banknotes caused contamination (these materials take moister and easily contamination by bacteria and fungi). Although the sensitivity test for bacteria done in this study which were shown some bacteria resistance for all antibiotic which was used and some of them multiple resistance.

\section{CONCLUSION}

In conclusion, this study showed that the paper Iraqi notes (250 and1000 IQD) are the most used contaminated currencies, because they were used by different people for providing daily goods, when these currencies contaminated by some pathogenic bacteria and contact human food or diets and speared between individual. This study also found that Iraqi notes in the form of coins that were used here, were showed relatively safer regarded contamination by bacteria and fungi.

\section{RECOMMENDATION}

As demonstrated in this study the coins could be safer than paper notes, it is recommended that the government should replace currencies to visa card safer than notes in general and encourage people to use coins for small exchange especially to children to buy goods. In other way the government should provide sterilized currencies by Ultraviolet (UV) or exchange the older currency and used the best material for making currency do not contaminate easily by pathogenic microbial.

\section{REFERENCES}

Abrams, B.I. and N.G. Waterman, 1972. Dirty money. JAMA, 219: 1202-3.

Ahlers, C., M. Martin, B. Olsen, P. O'Neil and M. Sanchez, 2010. How Green is Our Green? A Sustainability Assessment of U.S. and Australian Currency. ENVS 195 Sustainability Science.
Ahmed, M.S.U., S. Parveen, T. Nasreen and B. Feroza, 2010. Evaluation of the microbial contamination of Bangladesh paper currency notes (Taka) in circulation. Adv. Biol. Res., 4(5): 266-271.

Alton, G.G., L.M. Jones, R.D. Angus and J.M. Verger, 1988. Techniques for the Brucellosis Laboratory. INRA Publications, Paris, France, pp: 192.

Andrews, W.H. and T. Hammack, 2000. Bacteriological Analytical Manual. US Food and Drug Administration, FDA.

Atlas, R.M., A.E. Brown and L.C. Parks, 1995. Laboratory Manual Experimental Microbiology. Mosby-year Book, Inc., St. Louis.

Awe, S., K.I.T. Eniola, F.T. Ojo and A. Sani, 2010. Bacteriological quality of some Nigerian currencies in circulation. Afr. J. Microbiol. Res., 4(21): 22312234.

Ayandele, A.A. and S.A. Adeniyi, 2011. Prevalence and antimicrobial resistance pattern of microorganisms isolated from Naira notes in Ogbomoso North, Nigeria. J. Res. Biol., 8: 587593.

Barolia, S.K., S. Verma and B.K. Verma, 2011. Coliform contamination on different paper currency in Ajmer, Rajasthan, India. Universal J. Environ. Res. Technol., 1(4): 552-556.

Bernholtz, P., 2003. Monetary Regimes and Inflation: History, Economic and Political Relationships. Edward Elgar Publishing, Basle, Switzerland.

Bhat, N., S. Bhat, K. Asawa and A. Agarwal, 2010. An assessment of oral health risk associated with handling of currency notes. Int. J. Dental Clin., 2(4): 14-16.

Elumalai, E.K., E. David and J. Hemachandran, 2012. Bacterial contamination of Indian currency notes (Rupee). Int. J. Occup. Environ. Med., 3(4): 204205.

Enemuor, S.C., P.I. Victor and O.O. Oguntibeju, 2012. Microbial contamination of currency counting machines and counting room environment in selected commercial banks. Sci. Res. Essays, 14(7): 1508-1511.

Feglo, P. and M. Nkansah, 2010. Bacterial load on Ghanaian currency notes. Afr. J. Microbiol. Res., 4(22): 2375-2380.

Kramer, A., I. Schwebke and G. Kampf, 2006. How long do nosocomial pathogens persist on inanimate surfaces? A systematic review. BMC Infect. Dis., 6(1): 130.

Kuria, J.K., R.G. Wahome, M. Jobalamin and S.M. Kariuki, 2009. Profile of bacteria and fungi on money coins. East Afr. Med. J., 86(4): 151-155.

Lamichhane, J., S. Adhikary, P. Gautam, R. Maharjan and B. Dhakal, 2009. Risk of Handling paper currency in circulation chances of potential bacterial transmittance. Nepal J. Sci. Technol., 10: 161-166. 
Nasser, L.A. and S. Alwakeel, 2012. Bacterial and fungal contamination of Saudi Arabian paper currency and cell phones. Environ. Eng. Manage. J., 11(3): 72.

Oyero, O.G. and B.O. Emikpe, 2007. Preliminary investigation on the microbial contamination of Nigerian currency. Int. J. Infect. Diseases, 2(2): 2932.

Pradeep, N.V., Anupama, B.S. Marulasiddaiah, M. Chetana, P. Gayathri and S.N. Maduri, 2012. Microbial contamination of Indian currency notes in circulation. J. Res. Biol., 2(4): 377-382.

Prasai, T., K.D. Yami and D.R. Joshi, 2008. Microbial load on paper/polymer currency and coins. Nepal J. Sci. Technol., 9: 105-109.

Schaarschmidt, 1884. Upon the occurrence of bacteria and minute algae on the surface of paper money. Nature, 30: 360.
Shekarforoush, S., E. Khajeh Ali and M. Zarei, 2009. Evaluation of the bacterial contamination of the Iranian currency notes. Iran. J. Health Environ., 1(2): 81-88.

Tagoe, D., S.E. Baidoo, I. Dadzie and D. Ahator, 2010. A study of bacterial contamination of Ghanaian currency notes in circulation. Internet J. Microbiol., $8(2): 1-5$.

Umeh, E.U., J.U. Juluku and T. Ichor, 2007. Microbial contamination of 'Naira' (Nigerian Currency) notes in circulation. Res. J. Environ. Sci., 1(6): 336-339.

Vriesekoop, F., C. Russell, B. Alvarez-Mayorga, K. Aidoo, Q. Yuan, A. Scannell et al., 2010. Dirty money: An investigation into the hygiene status of some of the world's currencies as obtained from food outlets. Foodborne Pathog. Dis., 7(12): 1497502 . 